\title{
DETERMINATION OF ANTIBACTERIAL PROPERTIES OF MEDICAGO SATIVA L. (ALFALFA) EXTRACTS
}

\author{
Miss Anila Ghani, Asma Rehman \\ Associate professor Government Frontier College for Women's Peshawar, \\ Student of BS botany frontier college Peshawar \\ DOI: $10.31364 / \mathrm{SCIRJ} / \mathrm{v} 9.103 .2021 . \mathrm{P} 0321848$ \\ http://dx.doi.org/10.31364/SCIRJ/v9.i03.2021.P0321848
}

\begin{abstract}
Alfalfa, also called lucerne and called Medicago sativa in binomial nomenclature, is a perennial flowering plant in the legume family Fabaceae.Antibacterial activity of different solvent extracts of medicinal plant Medicago Sativa Leaves ,Root and Stem against clinical pathogen of human origin was find out.The antimicrobial activity of different solvents crude extract of Medicago Sativa plant root,stem and leaves was tested by disc diffusion and turbidity assay method against four bacterial pathogens $\mathrm{E}$ coli,S.typhi,K.pneumoniae and $\mathrm{S}$ aureous.After the result it showed that the antibacterial activity of the medicago sativa extract were increased with the increasing concentration of the crude extracts and polarity of the solvents used for extraction.
\end{abstract}

Key Words: Anti-microbial activity of medicago sativa,E coli,S.typhi,K.pneumoniae and S aureous, disc diffusion, polarity of medicago sativa.

\section{Introduction:}

Plants have been considered valuable for their therapeutic and comforting qualities in the whole world. People depend generally on the medicinal plants. The Food and Agriculture Organization estimated in 2002 that over 50,000 medicinal plants are used across the world. The Royal Botanic Gardens, Kew more conservatively estimated in 2016 that 17,810 plant species have a medicinal use, out of some 30,000 plants for which a use of any kind is documented.According to W.H.O 20 $\%$ of the individuals living in India are utilizing allopathic medicines while the remaining $80 \%$ depend on medicinal herbs as essential pill. The reason behind this dependence is that people believe in medicinal plants as a safe medication way. The engineered anticancer cures are past the span of normal man on account of heavy expense element. The only alternative safe way for cancer therapy is herbal medicines which can play a major role in cancer prevention. Common man can easily afford herbal medicine and medicinal herbs are easily available. (Sakarkar \& Deshmukh, 2011) Medicago sativa L. Perennial herb; stems erect or sometimes decumbent, 0.3-1 m long, 5-25 or more per crown, muchbranched,4-angled, glabrous or the upper part hairy; rhizome stout, penetrating the soil as much as 7-9 m; stipules united $1 / 3$ to $1 / 2$ length, free portion triangular lanceolate, tapering, basally entire or with 1-2 teeth,glabrous or sparingly appressed-hairy; leaves pinnately trifoliolate; leaflets obovate-oblong, ovate or linear, tapering to base, crenate above middle mostly retuse and mucronate, 10-45 mm long, 3-10 mm broad, glabrous or appressed hairy, paler green beneath; racemes oval or rounded, 1-2.5 $\mathrm{cm}$ long, 1-2 cm broad, inaxillary, 5- 40- flowered; peduncle slender, firm, always exceeding the subtending leaf, glabrous or appressedhairy; calyx tubular, with linear-subulate teeth longer then tube ;corolla yellow or blue to purple or violet, 6-15 mm long; bracteoles whitish, linear-subulate, mostly equaling the pedicel; pod slightly pubescent or glabrous, 3-9 $\mathrm{mm}$ in diameter, with 2-3 spirals, prominently reticulate-veined ;seeds 6 or 8 per pod, yellow, castaneous or brown, ovoid, irregularly cordate or reniform (Doss et al., 2011).

Phytoconstituents are the natural bioactive compounds found in plants. These phytoconstituents work with nutrients and fibers to form an integrated part of defense system against various iseases

\section{www.scirj.org}

(C) 2021, Scientific Research Journal

http://dx.doi.org/10.31364/SCIRJ/v9.i03.2021.P0321848

This publication is licensed under Creative Commons Attribution CC BY. 
and stress conditions. Phytochemicals are basically divided into two groups, i.e. primary and secondary constituents according to their functions in plant metabolism. Primary constituents comprise common sugars, amino acid, proteins and chlorophyll while secondary constituents consists of alkaloids, terpenoids, saponins, phenolic compounds, flavonoids, tannins and so on. Phytochemicals are naturally occurring biochemicals in plants that help to give plants their characteristic color, flavour, smell and texture. Apart from that,phytochemicals could prevent diseases (including cancer and cardiovascular diseases) and inhibit pathogenic microorganisms( Gomathi et al., 2013).

\section{MATERIAL AND METHODS Plan of work:}

\section{The work was plained as:}

The work takes 8 month of time period in completion which was performed in a very convient way step by step.

Step I the collection of the plants

\section{Step II: Crude Extract Prepared}

Step III:_Determined of Extractive values

Step IV: Determined of different Phytochemicals

Step V: Determined of Antibacterial Activity

\section{Procedure:}

\section{Samples Collection:}

The plants were collected from district Peshawar and identify were processed for different extractions and antibacterial activity in the Microbiology Laboratory of Abasyn University, Peshawar .

\section{Preparation of Crude Extract:}

Vegetative Parts of medicago sativa aong with root,were first chopped and then each part powder on the grinding machine. $150 \mathrm{gm}$ of powder on root stem and leaves of the plant have been taken and soaked in separate conical flasks $(500 \mathrm{ml})$ in distilled methanol (98\%) for overnight. On the next day the diluted extract were decant to another flask and filtered. The diluted extract was kept for evaporation of the solvent on the vacuum rotary evaporator at a temperature between $40-50^{\circ} \mathrm{C}$ and under reduced pressure. Again Methanol was added to the plant extract. This process was repeated three times for root, stem and leaves separately and the extract was dried completely.

\section{Determination of Extractive values:}

The extract obtained was then clarified and concentrated on a rotary evaporator undercontrol pressure and temperature between $30-45^{\circ} \mathrm{C}$. The semisolid extract was taken and weighed in a china dish and kept in a water bath at about $45^{\circ} \mathrm{C}$ dried. After complete drying these extracts was again weighed and the percentage yield of the extract was calculated using the equation. (Banso and Adeyemo, 2006).

Extractive value yield \%age = Weight of Extract/

Weight of Ground Plant Material×100

\section{Determination of different organic solvent extraction;}

On the bases of miscibility and different electronic configuration, different organic solvent, like hexane, chloroform, ethyl acetate and isobutanol used that phytochemicals were separated from each other. Each compound was evaporated and completely dried on a vacuum rotary evaporator under a control pressure and temperature between $40-50^{\circ} \mathrm{C}$. Dried extracts was diluted in $200 \mathrm{ml}$ distill water and transfer to separating funnel. About $150 \mathrm{ml}$ of Hexane were mixed to the separating funnel and was kept in shaker. Some of the substances were dissolved in the hexane. After 10-15min aqueous portion (water) and hexane were separated because hexane is insoluble in water. Due to high density aqueous portion were beneath the hexane. Three times was washed the aqueous portion with hexane. All the hexane soluble substances were removed from the extract and dried with vacuum rotary evaporator at a temperature $40^{\circ} \mathrm{C}$ under reduced wWw.scirj.org

(C) 2021, Scientific Research Journal

http://dx.doi.org/10.31364/SCIRJ/v9.i03.2021.P0321848

This publication is licensed under Creative Commons Attribution CC BY. 
pressure. The same process was applied for chloroform, ethyl acetate and isobutanol.

\section{Phytochemical screening;}

Phytochemical screening of the prepare extracts was conducted with various qualitative test to identify the presence of various chemical constituents. Performed the tests of the following chemicals and reagent were used. These were identified by characteristic color changes using standard procedures. (Ghani2003)

\section{Chemical Test:}

Tests for Alkaloids: Dragendroff's test. Mayer's test. Tests for Glycosides: Modified

Borntrager's Test. Tests for Flavanoids:

Shinoda test. Test of Triterpenoids:

Liebermann -Burchard's test. Detection of phytosterols: Salkowski's Test. Detection of Saponins: Foam test. Detection of phenols: ferric chloride test. Detection of amino acid:

Ninhydrin test.

\section{Antibacterial Activity:}

The extract of different parts of the plant has been tested for its sensitivity against the selected resistant bacteria. The species of Bacteria have been obtained from microbiology laboratory Abasyn University, Peshawar. These microbes were grown and further processed for susceptibilities against these extract according to the standard microbiological procedure.

\section{$\underline{\text { Bacterial strains }}$}

Bacterial strains were used in this study was the isolated pathogens such as Staphylococcus aureus, Escherichia coli, Klebsiella pneumoniae and Salmonella typhi, All the strains were confirmed by cultural and biochemical characteristics and maintained in slants for further use.

\section{Medicago SativaL. leaves Phytochemicals extraction:}

Leaves dry powder weight $248 \mathrm{gm}$

Round Bottem Flask empty weight $358.5 \mathrm{gm}$

wwW.scirj.org

(C) 2021, Scientific Research Journal

http://dx.doi.org/10.31364/SCIRJ/v9.i03.2021.P0321848

This publication is licensed under Creative Commons Attribution CC BY.
Antibacterial sensitivity testing using Disc diffusion method:

This method depend on the diffusion of antibiotic from vertical cylinder or cavity through the solidified ager layer of petridish or plate to an extent such that growth of added micro organism In a circular area is presented Inoculums of each of the bacterial strains (single colony) was suspended in $5 \mathrm{ml}$ of broth (nutrient broth) and incubated at $37^{\circ} \mathrm{C}$ for $18 \mathrm{hr}$. The antibacterial activity was tested by the disc diffusion assay7. $0.1 \mathrm{ml}$ of inoculums (105 $\mathrm{CFU} / \mathrm{ml}$ ) was spread on sterile Mueller Hinton plates and sterile paper discs were placed on the inoculated surface. After solidifying media, holes were made by $5 \mathrm{~mm}$ cork borer. Each hole was filled with 50ul of plant extract. The discs were impregnated with $50 \mu \mathrm{l}$ of each of the extract at two different concentration $(.2 / 2 \mathrm{mg} / \mathrm{ml} \& 2 / 5 \mathrm{mg} / \mathrm{ml})$, kept at room temperature for absorption of extract in the medium and then incubated at $37^{\circ} \mathrm{C}$ in the incubator for $24 \mathrm{hr}$. The antibacterial activity was evaluated by measuring the diameter of inhibition zone as per the procedure described by Kim et al.8. Ciprofloxacin was used simultaneously as control. .( Doss et al.2012)

\section{Minimum Inhibitory Concentration (MIC)}

For determination of MIC, $1 \mathrm{ml}$ of broth medium was taken into 10 test tubes for each Bacteria. Different concentrations of plant extracts ranging from 0.125 to $8 \mathrm{mg} / \mathrm{ml}$ concentration were incorporated into the broth and the tubes were then inoculated with $0.1 \mathrm{ml}$ of inoculum of respective

\section{Results}

bacteria $(105 \mathrm{CFU} / \mathrm{ml})$ and kept at $37^{\circ} \mathrm{C}$ for $24 \mathrm{hr}$. The test tube containing the lowest concentration of extract which showed reduction in turbidity, when compared with control was regarded as MIC of that extract.

The strongest antibacterial activity with MIC values of $0.05 \mathrm{mg} / \mathrm{ml}-0.50 \mathrm{mg} / \mathrm{ml}$, moderate activity values between $0.6 \mathrm{mg} / \mathrm{ml}-1.50 \mathrm{ml} / \mathrm{mg}$ and weak activity above $1.50 \mathrm{mg} / \mathrm{ml}$..( Doss et al.2012) 
R B F +Methanolic extract weight $379.8 \mathrm{gm}$

Crude methanolic extract weight $21.3 \mathrm{gm}$

Extractive value yield \%age $=$ Weight of Extract/ Weight of Ground Plant Material $\times 100$ (1)

\begin{tabular}{|c|c|c|c|c|c|c|c|}
\hline \multicolumn{2}{|c|}{ Hexane fraction } & \multicolumn{2}{|c|}{ Ethyl acetate fraction } & \multicolumn{2}{|c|}{ Isobutanol fraction } & \multicolumn{2}{|l|}{ Water fraction } \\
\hline $\begin{array}{l}\text { RBF } \\
\text { Empty wt }\end{array}$ & $189.9 \mathrm{gm}$ & $\begin{array}{l}\text { Vail empty } \\
\text { wt }\end{array}$ & $13.21 \mathrm{gm}$ & $\begin{array}{l}\text { RBF empty } \\
\text { wt }\end{array}$ & $106 \mathrm{gm}$ & $\begin{array}{l}\text { RBF empty } \\
\text { wt }\end{array}$ & $189.9 \mathrm{gm}$ \\
\hline $\begin{array}{l}\text { RBF+ } \\
\text { Extract }\end{array}$ & $194.5 \mathrm{gm}$ & Vail+extract & $14.021 \mathrm{gm}$ & $\begin{array}{l}\mathrm{RBF}+ \\
\text { extract }\end{array}$ & $109.5 \mathrm{gm}$ & $\mathrm{RBF}+$ extract & $196 \mathrm{gm}$ \\
\hline $\begin{array}{l}\text { Hexane } \\
\text { extraction } \\
\text { value }\end{array}$ & $4.6 \mathrm{gm}$ & $\begin{array}{l}\text { Extractiv } \\
\text { value }\end{array}$ & $0.841 \mathrm{gm}$ & $\begin{array}{l}\text { Extractive } \\
\text { value }\end{array}$ & $0.841 \mathrm{gm}$ & $\begin{array}{l}\text { Extractive } \\
\text { value }\end{array}$ & $6.1 \mathrm{gm}$ \\
\hline $\begin{array}{l}\text { Extective } \\
\text { value } \\
\text { yield } \%\end{array}$ & $1.9 \%$ & $\begin{array}{l}\text { Extective } \\
\text { value } \\
\text { yield } \%\end{array}$ & $.339 \%$ & $\begin{array}{l}\text { Extective } \\
\text { value } \\
\text { yield } \%\end{array}$ & $.339 \%$ & $\begin{array}{l}\text { Extective } \\
\text { value } \\
\text { yield\% }\end{array}$ & $2.5 \%$ \\
\hline
\end{tabular}

Table2 : List of Medicago sativa different extracts used to evaluate antimicrobial activity.

\begin{tabular}{|l|l|l|}
\hline No & Name & Colour of used extract \\
\hline 1 & Ethyl acetate & Light green \\
\hline 2 & isobutanol & Dark green \\
\hline 3 & Hexane & Green yellow \\
\hline 4 & Hot aqueous extract & Green \\
\hline 5 & Cold aqueous extract & Green \\
\hline
\end{tabular}

\section{Medicago sativaL. root Phytochemicals extraction}

Root dry powder weight $246 \mathrm{gm}$

China dish empty weight $777.1 \mathrm{gm}$

China dish + extract weight 788.8gm

Crude methanolic extract weight $11.7 \mathrm{gm}$

Table 3

\begin{tabular}{|c|c|c|c|c|c|c|c|}
\hline \multicolumn{2}{|c|}{ Hexane fraction } & \multicolumn{2}{|c|}{ Ethyl acetate fraction } & \multicolumn{2}{|c|}{ Isobutanol fraction } & \multicolumn{2}{|l|}{ Water fraction } \\
\hline $\begin{array}{l}\text { RBF } \\
\text { Empty wt }\end{array}$ & $106 \mathrm{gm}$ & $\begin{array}{l}\text { RBF empty } \\
\text { wt }\end{array}$ & $106 \mathrm{gm}$ & $\begin{array}{ll}\text { RBF empty } \\
\text { wt }\end{array}$ & $106 \mathrm{gm}$ & $\begin{array}{ll}\text { RBF empty } \\
\text { wt }\end{array}$ & $105.8 \mathrm{gm}$ \\
\hline $\begin{array}{l}\text { RBF+ } \\
\text { Extract }\end{array}$ & $\begin{array}{l}107.437 \mathrm{~g} \\
\mathrm{~m}\end{array}$ & RBF+ extract & $106.8 \mathrm{gm}$ & $\begin{array}{l}\text { RBF+ } \\
\text { extract }\end{array}$ & $108.9 \mathrm{gm}$ & RBF+ extract & $110.5 \mathrm{gm}$ \\
\hline $\begin{array}{l}\text { Hexane } \\
\text { extraction } \\
\text { value }\end{array}$ & $1.437 \mathrm{gm}$ & $\begin{array}{l}\text { Extractiv } \\
\text { value }\end{array}$ & $0.8 \mathrm{gm}$ & $\begin{array}{l}\text { Extractive } \\
\text { value }\end{array}$ & $2.9 \mathrm{gm}$ & $\begin{array}{l}\text { Extractive } \\
\text { value }\end{array}$ & $4.7 \mathrm{gm}$ \\
\hline $\begin{array}{l}\text { Extective } \\
\text { value } \\
\text { yield } \%\end{array}$ & $.581 \%$ & $\begin{array}{l}\text { Extective } \\
\text { value } \\
\text { yield } \%\end{array}$ & $.325 \%$ & $\begin{array}{l}\text { Extective } \\
\text { value } \\
\text { yield } \%\end{array}$ & $1.17 \%$ & $\begin{array}{l}\text { Extective } \\
\text { value } \\
\text { yield\% }\end{array}$ & $1.9 \%$ \\
\hline
\end{tabular}

www.scirj.org

(C) 2021, Scientific Research Journal

http://dx.doi.org/10.31364/SCIRJ/v9.i03.2021.P0321848

This publication is licensed under Creative Commons Attribution CC BY. 


\section{Medicago sativaL. Stem Phytochemicals extraction}

Root dry powder weight $153 \mathrm{gm}$

China dish empty weight $358.5 \mathrm{gm}$

China dish + extract weight 378.4gm

Crude methanolic extract weight $19.9 \mathrm{gm}$

Table4

\begin{tabular}{|c|c|c|c|c|c|c|}
\hline \multicolumn{2}{|c|}{ Ethyl acetate fraction } & \multicolumn{2}{|c|}{ Isobutanol fraction } & \multicolumn{3}{|c|}{ Water fraction } \\
\hline $106 \mathrm{gm}$ & $\begin{array}{l}\text { RBF empty } \\
\text { wt }\end{array}$ & $113 \mathrm{gm}$ & $\begin{array}{ll}\text { RBF empty } \\
\text { wt }\end{array}$ & $106 \mathrm{gm}$ & $\begin{array}{l}\text { RBF empty } \\
\text { wt }\end{array}$ & $113 \mathrm{gm}$ \\
\hline $110.7 \mathrm{gm}$ & $\mathrm{RBF}+$ extract & $113.5 \mathrm{gm}$ & $\begin{array}{l}\mathrm{RBF}+ \\
\text { extract }\end{array}$ & $108.5 \mathrm{gm}$ & RBF+ extract & $122.5 \mathrm{gm}$ \\
\hline $4.7 \mathrm{gm}$ & $\begin{array}{l}\text { Extractiv } \\
\text { value }\end{array}$ & $0.5 \mathrm{gm}$ & $\begin{array}{l}\text { Extractive } \\
\text { value }\end{array}$ & $2.4 \mathrm{gm}$ & $\begin{array}{l}\text { Extractive } \\
\text { value }\end{array}$ & $9.5 \mathrm{gm}$ \\
\hline $3.07 \%$ & $\begin{array}{l}\text { Extective } \\
\text { value } \\
\text { yield\% }\end{array}$ & $.33 \%$ & $\begin{array}{l}\text { Extective } \\
\text { value } \\
\text { yield } \%\end{array}$ & $1.57 \%$ & $\begin{array}{l}\text { Extective } \\
\text { value } \\
\text { yield } \%\end{array}$ & $6.2 \%$ \\
\hline
\end{tabular}

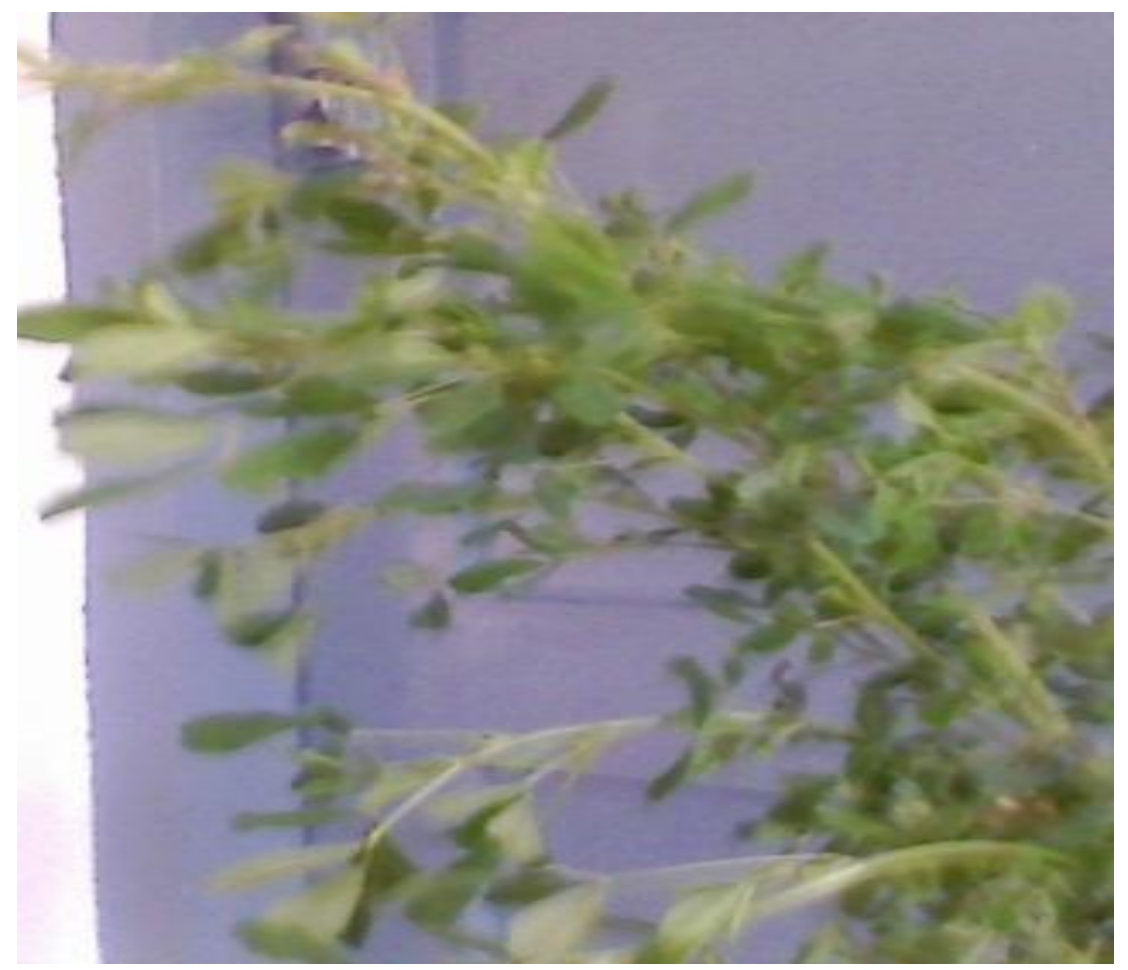

Fig;1

\section{Antibacterial activity of Medicago Sativa leaf against selected pathogens}

\section{Table 8}


Scientific Research Journal (SCIRJ), Volume IX, Issue III, March 2021

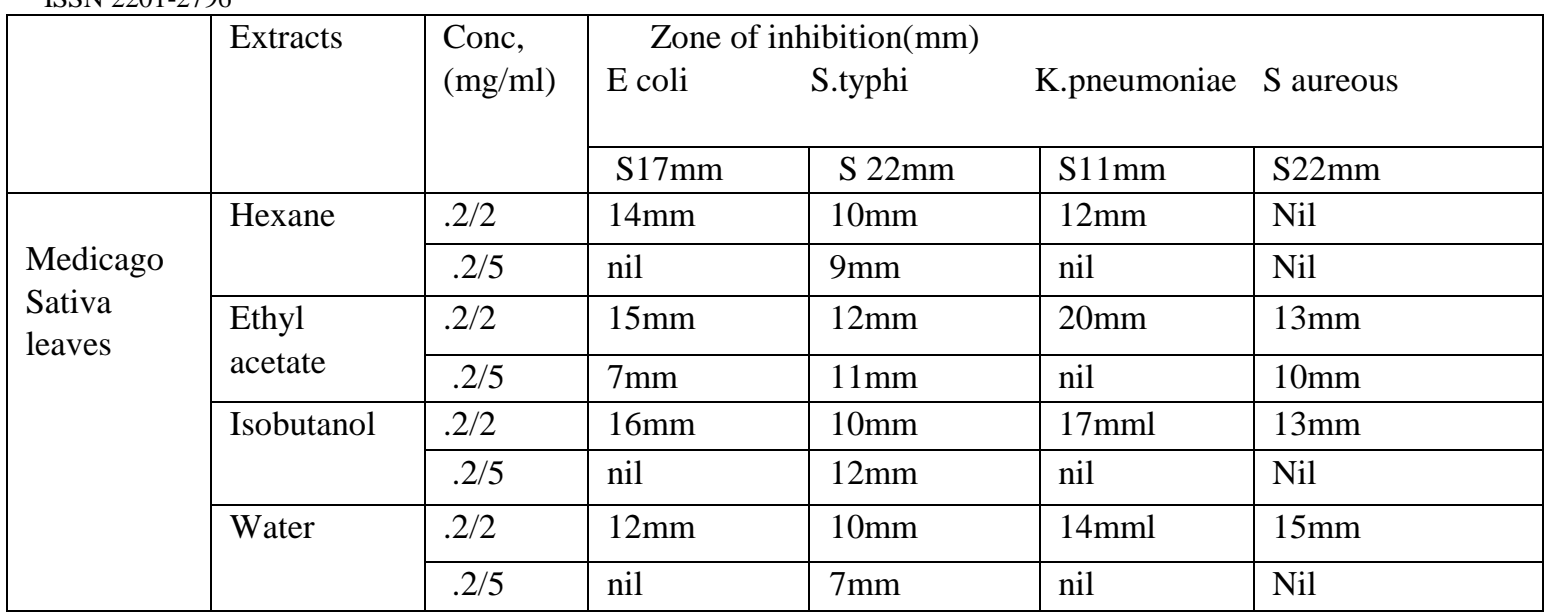

Table 9

Antibacterial activity of Medicago Sativa stem against selected pathogens

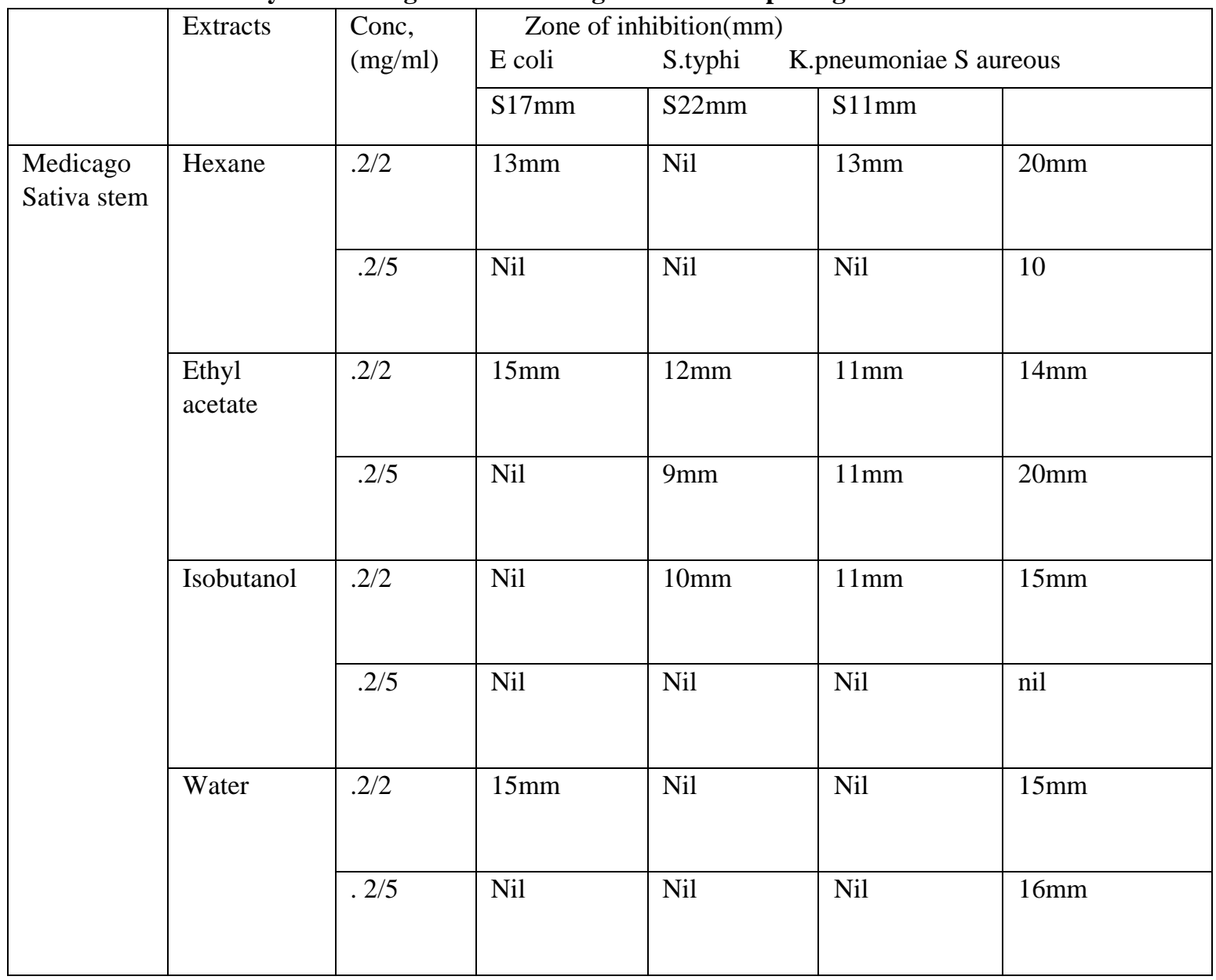

Www.scirj.org

(C) 2021, Scientific Research Journal

This publication is licensed under Creative Commons Attribution CC BY. 


\section{Table 10}

Antibacterial activity of Medicago Sativa root against selected pathogens

\begin{tabular}{|c|c|c|c|c|c|c|}
\hline & \multirow[t]{2}{*}{ Extracts } & \multirow{2}{*}{$\begin{array}{l}\text { Conc, } \\
(\mathrm{mg} / \mathrm{ml})\end{array}$} & \multicolumn{3}{|c|}{ Zone of inhibition(mm) } & \multirow[b]{2}{*}{ S aureous } \\
\hline & & & E coli & S.typhi & K.pneum & \\
\hline & & & $\mathrm{S} 17 \mathrm{~mm}$ & $\mathrm{~S} 22 \mathrm{~mm}$ & $\mathrm{~S} 11 \mathrm{~mm}$ & $\mathrm{~S} 22 \mathrm{~mm}$ \\
\hline \multirow{8}{*}{$\begin{array}{l}\text { Medicago } \\
\text { Sativa root }\end{array}$} & \multirow[t]{2}{*}{ Hexane } & $.2 / 2$ & $12 \mathrm{~mm}$ & $11 \mathrm{~mm}$ & $13 \mathrm{~mm}$ & $19 \mathrm{~mm}$ \\
\hline & & $.2 / 5$ & nil & nil & nil & $12 \mathrm{~mm}$ \\
\hline & \multirow{2}{*}{$\begin{array}{l}\text { Ethyl } \\
\text { acetate }\end{array}$} & $.2 / 2$ & nil & nil & $11 \mathrm{~mm}$ & $26 \mathrm{~mm}$ \\
\hline & & $.2 / 5$ & nil & nil & $17 \mathrm{~mm}$ & $17 \mathrm{~mm}$ \\
\hline & \multirow[t]{2}{*}{ Isobutanol } & $.2 / 2$ & $19 \mathrm{~mm}$ & $10 \mathrm{~mm}$ & $11 \mathrm{~mm}$ & Nil \\
\hline & & $.2 / 5$ & $11 \mathrm{~mm}$ & nil & nil & $16 \mathrm{~mm}$ \\
\hline & \multirow[t]{2}{*}{ Water } & $.2 / 2$ & $14 \mathrm{~mm}$ & nil & nil & $8 \mathrm{~mm}$ \\
\hline & & $.2 / 5$ & nil & nil & nil & $19 \mathrm{~mm}$ \\
\hline
\end{tabular}

\section{Antibacterial activity of .2mg/2ml Medicago Sativa leaf concentration against selected pathogens}

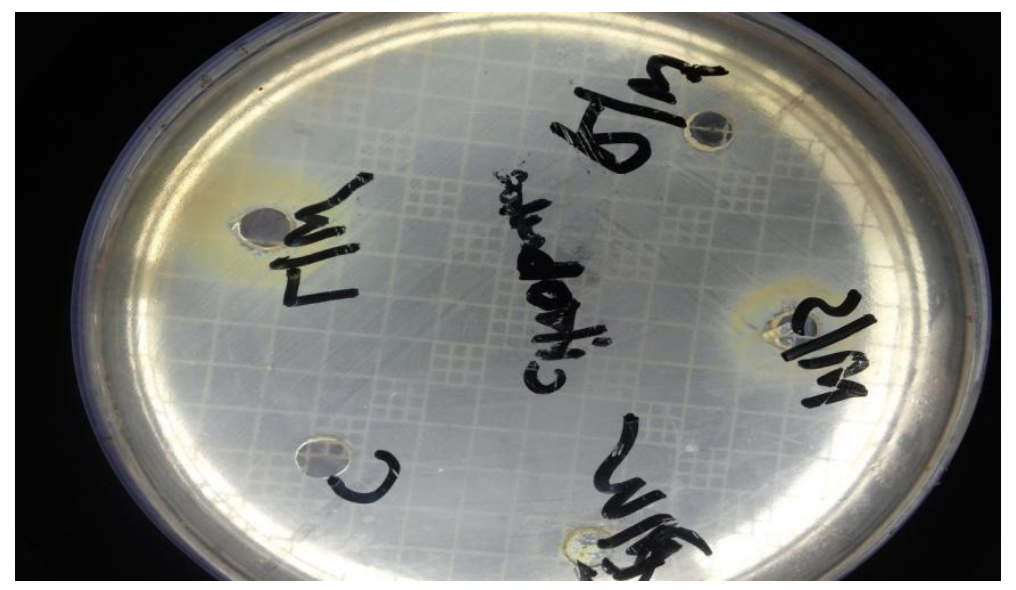

Fig16 

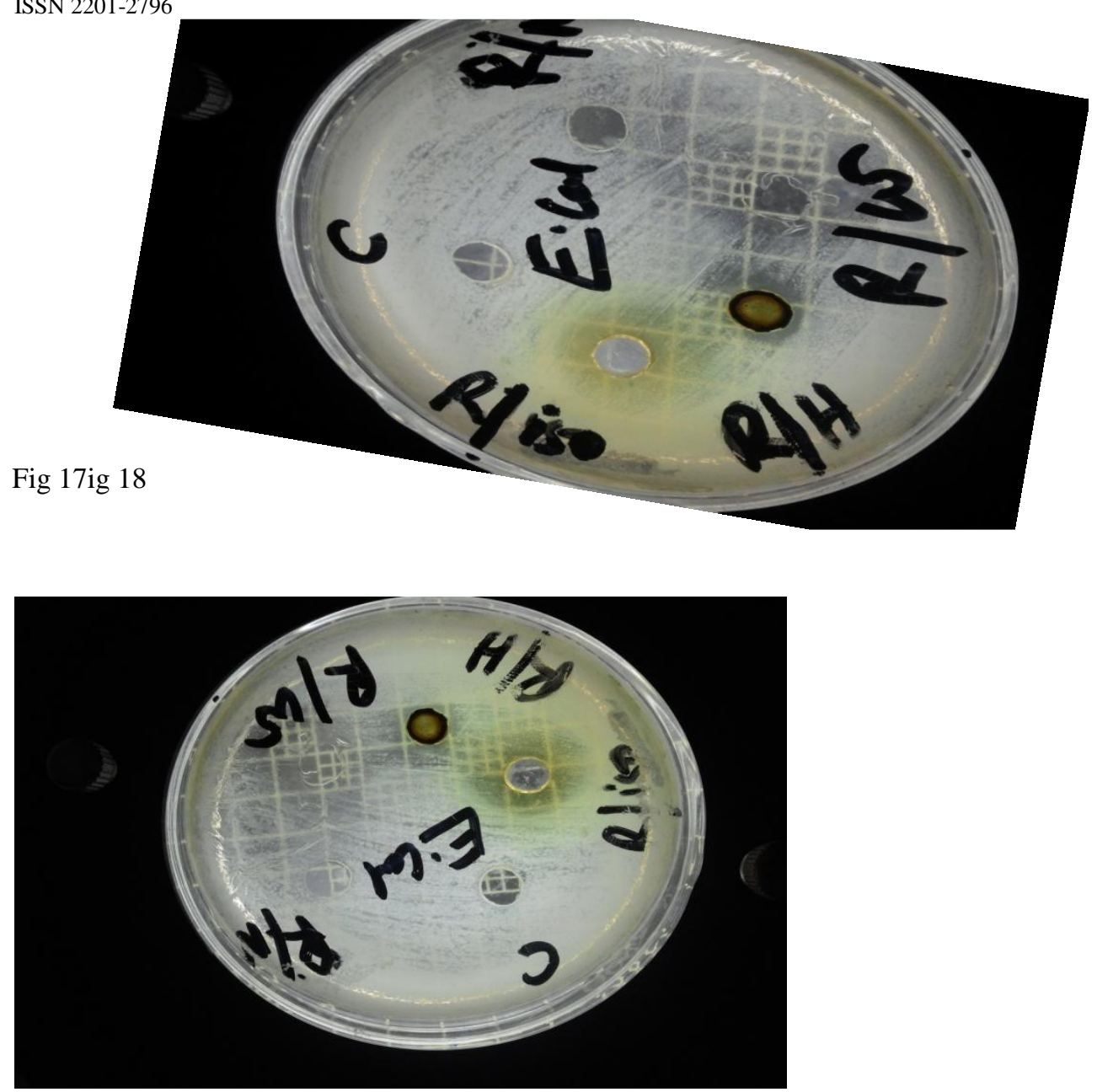

Fig 19

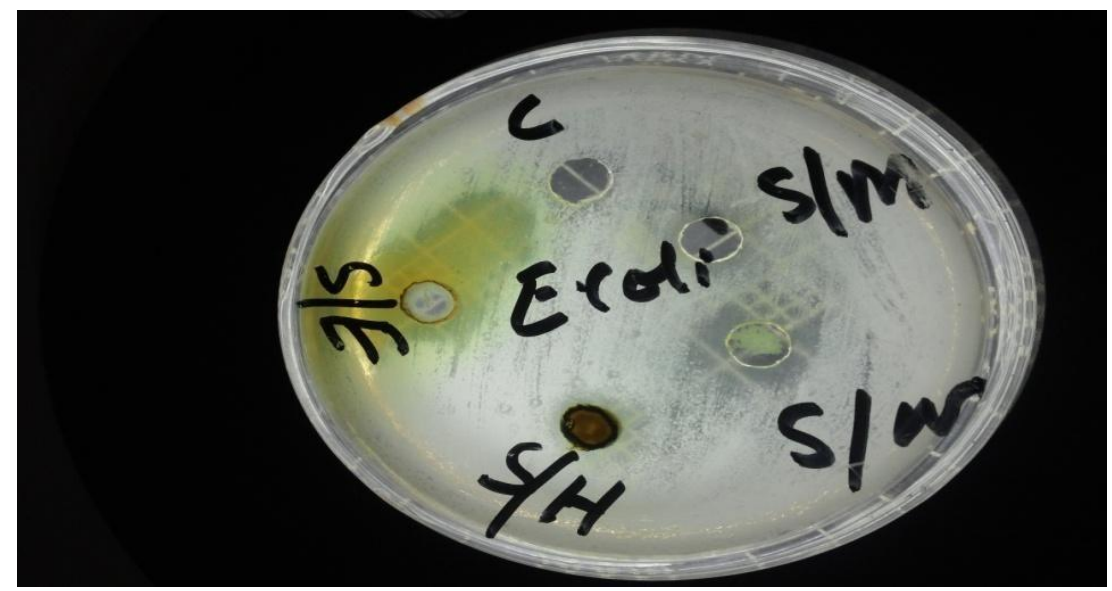

\section{E.Coli ;stem extract applied}

,w=water $\mathrm{C}=$ standerd $\mathrm{E}=$ ethyl acetate, $\mathrm{I}=$ isobutanol, $\mathrm{H}=$ =xane 
In the Disc Diffusion assay the zone of inhibition around the disc impregnated with plant extract over the bacterial culture plates quantatively determined the antibacterial activity.The result showed that the antibacterial activity of the plant extract were increased with the increasing concentration of the crude extracts and polarity of the solvents used for extraction.

The plates were incubated overnight at 370C. Antimicrobial activity was determined by measuring the diameter of zone of inhibition around the colonies (Blum, U, 1985). For each bacterial strain, controls were maintained where pure solvents were used instead of the extract.
Medicago Sativa leaves water extract showed more prominent result against Klebsella pneumoniae $\mathrm{S}$ aureus ,better result in $\mathrm{E}$ coli ,S typhi.

The inhibition activity was determined by measuring the diameter of the clear zone .The diameter of the clear zone indicated the inhibition activity.The iso butanol extract is the most effective against E.Coli and Klebsella pneumonia followed by Ethyl acetate extract showed significant antibacterial activity against Klebsella pneumonia ,S aureus and Ecoli. The hexane extract showed strong inhibition against $\mathrm{K}$ pneumonia and aqueous extract did not show any significant antibacterial activity.

\section{Antibacterial activity of $.2 / 5 \mathrm{mg} / \mathrm{ml}$ concentration ofMedicago Sativa leaf/stem/root against selected pathogens}

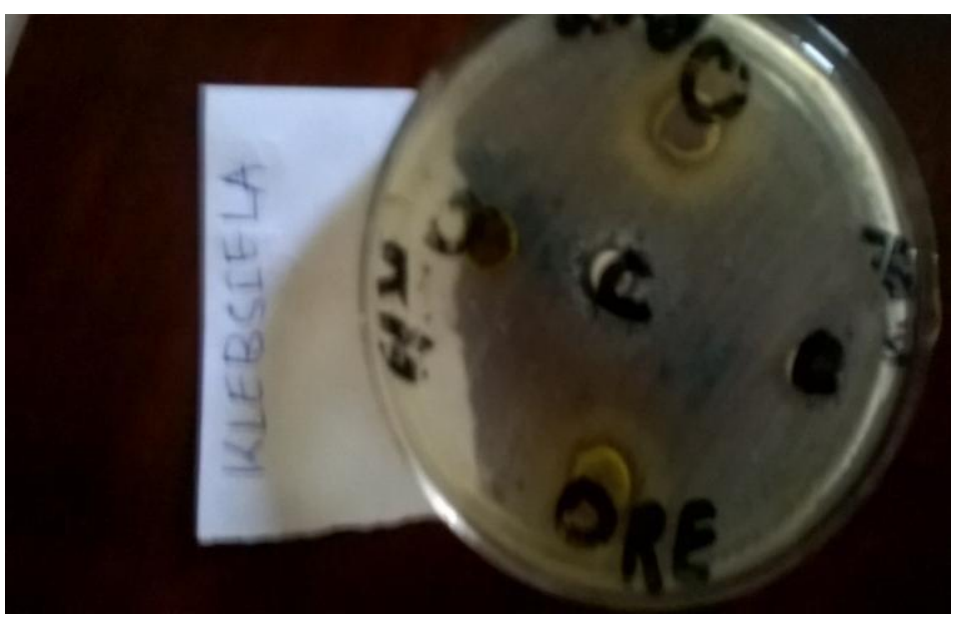

Fig 21

www.scirj.org

(C) 2021, Scientific Research Journal 


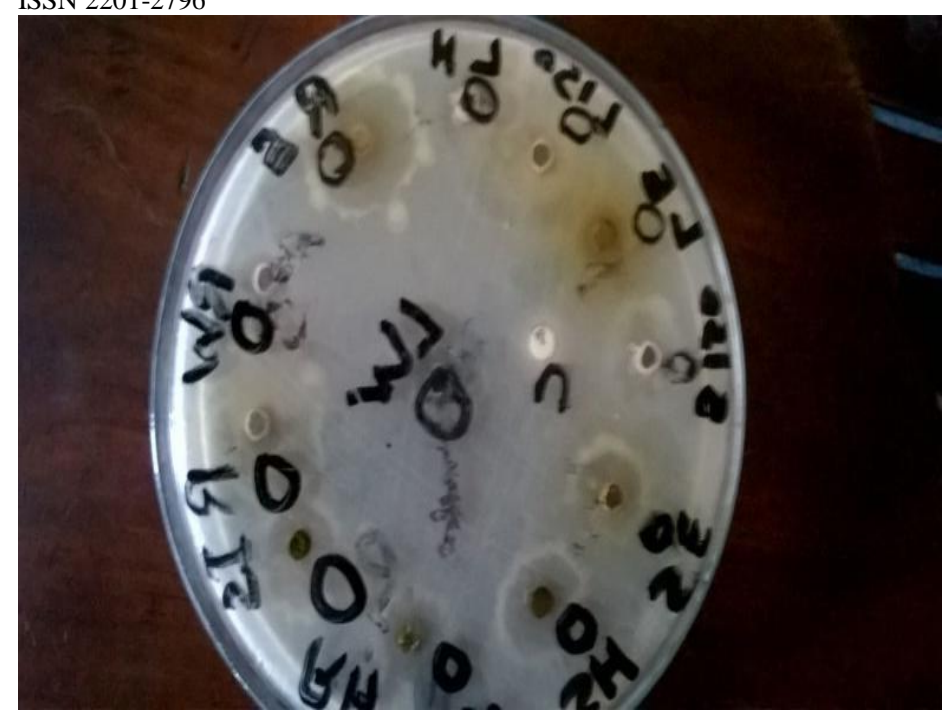

Fig22

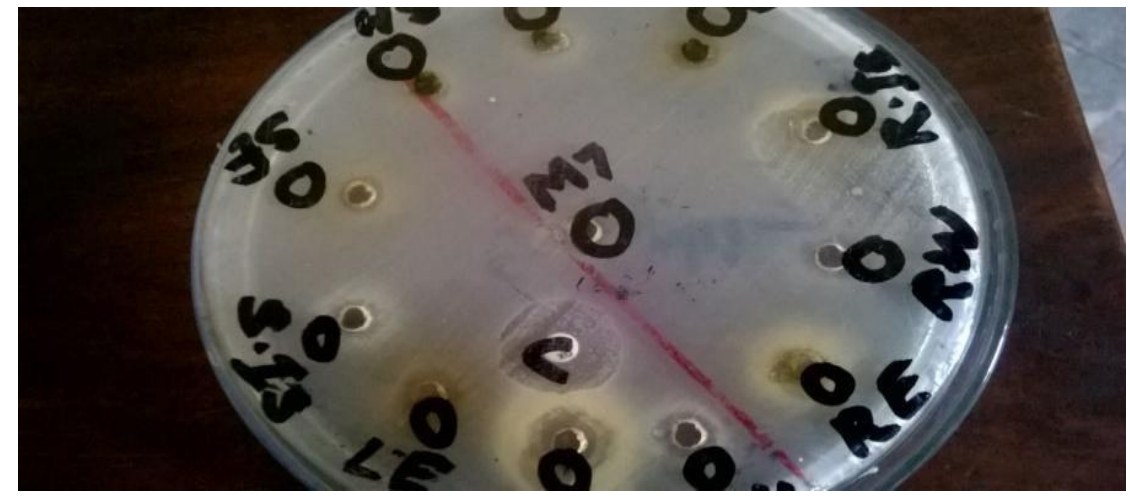

Fig23

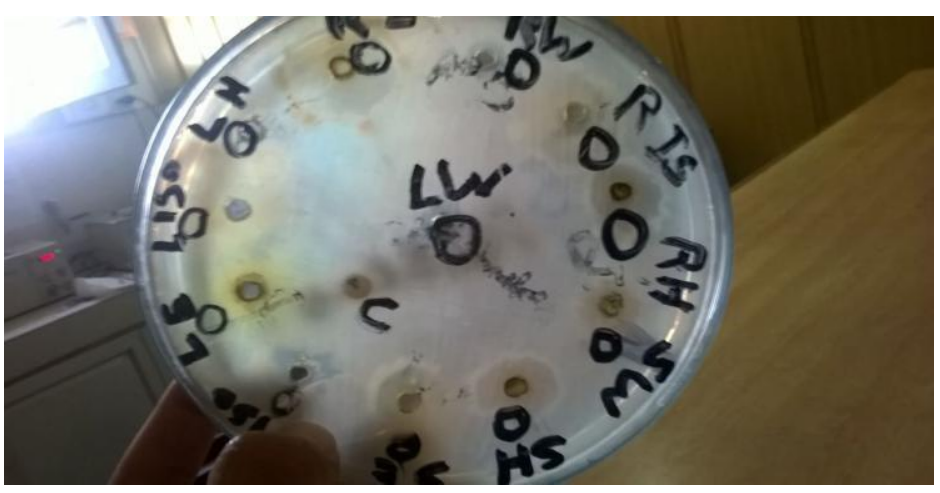

www.scirj.org

(C) 2021, Scientific Research Journal

http://dx.doi.org/10.31364/SCIRJ/v9.i03.2021.P0321848

This publication is licensed under Creative Commons Attribution CC BY. 
Fig24

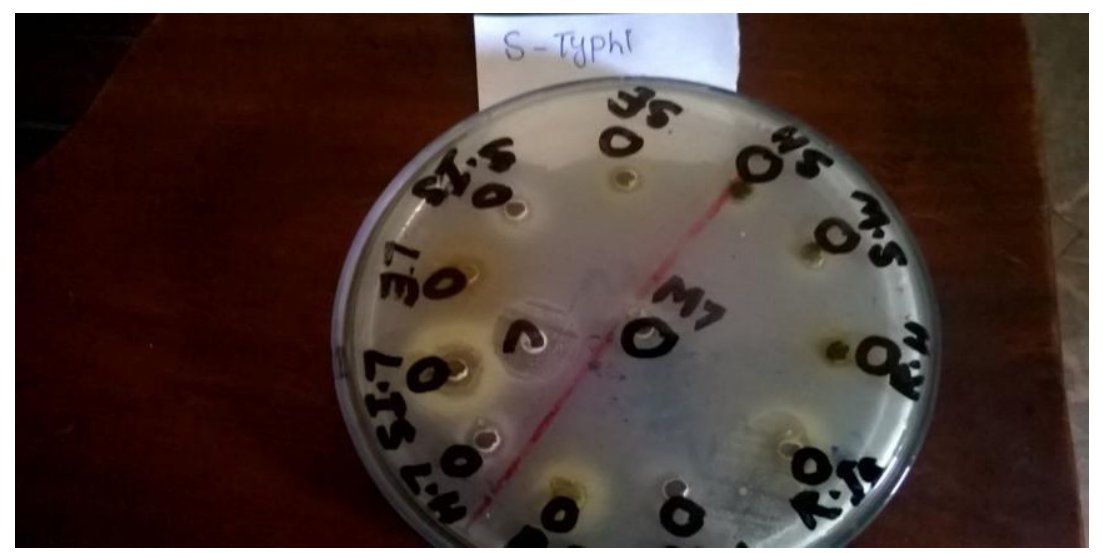

\section{Fig25}

Extract applied on S.Typhe

$\mathrm{LW}=$ leaf water extract , LIS=Leaf isobutanol extract ,LH=Leaf hexane extract, LE,Leaf ethylacetate extract

$\mathrm{RW}=$ Root water extract , RIS=Root isobutanol extract, $\mathrm{RH}=$ Root hexane extract, RE=Root ethylacetate extract

$\mathrm{SW}=$ Stem water extract, $\mathrm{SIS}=\mathrm{Stem}$ isobutanol extract, $\mathrm{SH}=\mathrm{Stem}$ hexane extract, $\mathrm{SE}=\mathrm{Stem}$ ethylacetate extract

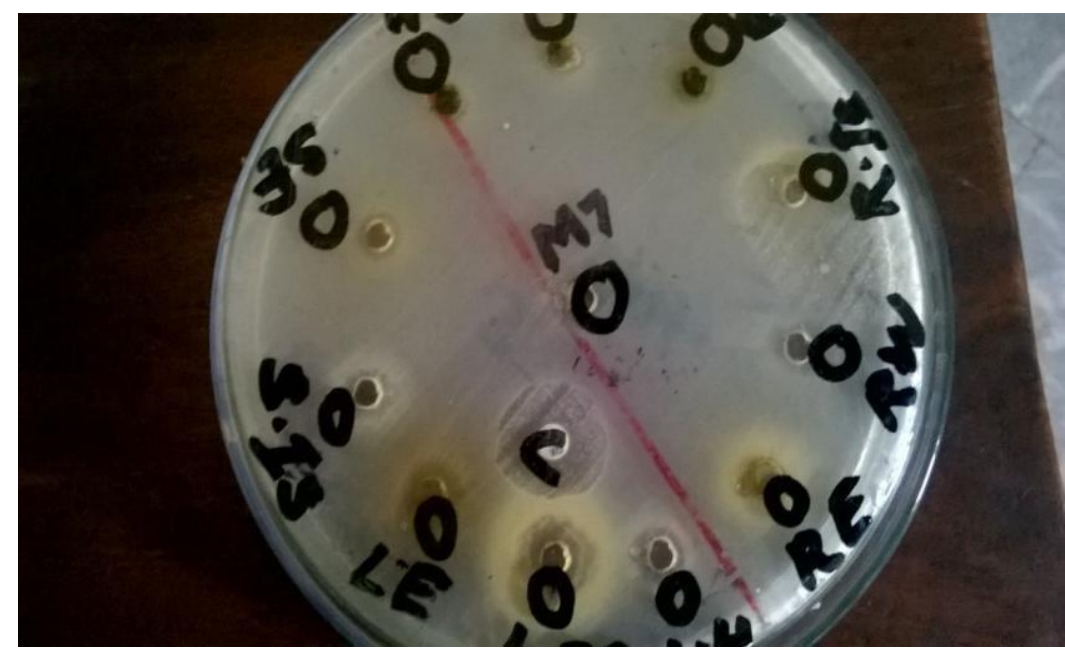

The use of herbs in medicine is common all over world. About one third of adults in the world use of alternative therapies including plants which may be used distinctly or united in a mixtures. In the contrary to chemical Company). drugs, plant sainted to be harmless, due to its natural defilement, pollution, toxicity, substitution. This useless truth maintain the study of medicinal plants and plant compounds utilized in medicine. extract is the only extract showed high antibacterial effect source. However, problems may generate due to wrong identification and require of standardization . However the revolution of man-made antibiotics, the diseases due to bacteria is silent of main be anxious in medicine, due to the amount of antibiotic anti strains which enhancing the interest to use natural products due to their advanced biodegradability and accessibility. In this view, the study was achieved to discover the antimicrobial activity of Medicago sativa aqueous and solvent extracts on some medically important human pathogen (S. aureus, E. coli, Salmonella typhimurium, and K. pneumoniae) by agar well diffusion method.

All plant parts in order to perform their physiological activities form some chemicals by themselves, in the present study, M. sativa produce different kinds of secondary

www.scirj.org

(C) 2021, Scientific Research Journal

http://dx.doi.org/10.31364/SCIRJ/v9.i03.2021.P0321848

This publication is licensed under Creative Commons Attribution CC BY. 
metabolites which play an important role medicinally. A plant studies involve extraction of the active component in the plants using organic solvents. But plants as used in traditionally, using organic solvent extraction for the antibacterial properties should not be done often; therefore, in the present study the commonly used plants extracts are made with distilled water, different organic solvent extracts and tested for its antimicrobial effect against S. aureus, E. coli and $\mathrm{K}$. pneumoniae and $\mathrm{S}$ typhimurium. All plants used in the herbal medicine mostly have best antimicrobial activities as determined earlier.

According to Venkataswamy et al. the Grampositive bacterial strains were more susceptible to the activity of the aqueous M.sativa leaf ,stem and root extracts when compared to gram negative bacteria. This may be explained due to the fact that these two groups have different cell wall structure. The capability of tannin compounds which detrmined to be present in M. sativa break ups the bacterial colonies, by its disruption with the bacterial cell wall. Considering the above results, our result was found the extreme antibacterial activity in Medicago sativa against Gram positive S.aureus K. pneumoniae , as estimate to Gram negativeE.coli.as shown in Table (8) and Figure (16) The antimicrobial activity of saponins isolated from M. Sativa against selected medically important Grampositive and Gram-negative bacteria has been examined. Increasing antibiotic activity was observed going from the isobutanol extracts. Activity was found particularly high against Grampositive bacteria (9) declared that the superior antibacterial activity of M.sativa extract to E.coli and where the antibacterial effects on E.coli and S. aureus were normal. However this search of antimicrobial activity was carried out on six different extracts of M. sativa as shown in (Table 10 . The screening step in the startning study for antimicrobial activity was done using the Agar well Diffusion Method. The diameter of the clear zone showed the inhibition activity. The The iso butanol extract is the most effective against E.Coli and Klebsella pneumonia followed by Ethyl acetate extract showed significant antibacterial activity against Klebsella pneumonia , $\mathrm{S}$ aureus and Ecoli. The hexane extract showed strong inhibition against $\mathrm{K}$ pneumonia and aqueous extract did not show any significant antibacterial activity.The isobutanol extract is the mainly successful against $\mathrm{S}$. aureus followed by other extract observed major antibacterial activity against Salmonella typhimurium, K. pneumoniae, S.aureus and E. coli. as shown in Table ( 8) and Figure (17) The results of our study showed that ethanol extract 5. In-vitro of Medicago sativa possess very potential antibacterial effect on $\mathrm{K}$ pneumonia as shown in Table (9) and Figure (18).,(20,21,22)Also All phytochemical tests results indicated that Medicago sativa contain flavonoids, tannins, alkaloids, saponin and glycosides compounds as shown in Table (9). Antimycobacterial properties of the plant could be due to the abundant flavonoids, saponins and tannins that were found in it Table (3). Phytochemical constituents such as tannins, saponins, flavonoids, alkaloids and several other aromatic compounds are secondary metabolites of plants that serve as defense mechanisms against predation by many microorganisms, insects and other herbivores Therefore, in order to get valuable antimicrobial activity at low concentrations without any consequences on the health researches should center of attention on the optimization of purification and uses.

\section{CONCLUSIONS}

From all the above, it is concluded that the Medicago sativa extract exhibited significant antimicrobial activity against microbial pathogens and can be initiated as an choice to chemical antimicrobial drugs, but it entails broader search. Also the data propose that the methanolic extract of M. sativa could be a rich source of antimicrobial agents. Those outcomes have been promote to perform further tests to authenticate the precise use of the studied extracts to treat the bacterial and caused by bacteria found to be receptive to our extracts

\section{ACKNOWLEDGEMENT}

Both authors (aneela ghani, Asma Rehman) are grateful to the Absyn University and Frontier college the lab support given to the present study isolated bacterial pathogens. The authors are thankful to the chairman M Shabir and labe assistnt Jamshed and miss gulnaz for their encouragement and support.

\section{Refrences/Literature Review:}

Aliahmadi,A, Rasoul Roghanian, Giti Emtiazi,

Fatemeh Mirzajani and Alireza.Identification and Primary characterization of a plant antimicrobial peptide with remarkable Inhibitory

effects against antibiotic resistant bacteria African Journal of Biotechnology, 2012, Vol. 11(40); 9672-9676.

A Banso ,S Adeyemo ,Biochemistry, 2006,18; 39-44 Anklesaria. B.S., The promise of phytoestrogens.

Indian J. Pharmacol, 2011, 43, 369 -370.

Doss. A. V., Parivuguna, M. Vijayasanthi and Sruthi

Surendran, Antibacterial

www.scirj.org

(C) 2021, Scientific Research Journal http://dx.doi.org/10.31364/SCIRJ/v9.i03.2021.P0321848

This publication is licensed under Creative Commons Attribution CC BY. 
Evaluation and phytochemical analysis of

Medicago sativa L. against some

Microbial pathogens. Indian Journal of Science and Technology, 2011, Vol. 4 No.

5, ISSN: 0974- 6846.

Cowan MM. Plant products as antimicrobial agents.

Clin. Microbiol. Rev. 12: 564582

from alfaalfa seeds on the population

Biology of Bacillus cereus. Appl.

Environ. Microbiol. 1999. 64(12): 4683-4688.

Colodny LR, Montgomery A, Houston M . The Role of Esterin Processed Alfalfa Saponins in

Reducing Cholesterol, Journal of the American

Nutraceutical Association., (Winter

$2001 ; \mathrm{Vol}$

3, No 4:1.

Doss. A. V., Parivuguna, M. Vijayasanthi and Sruthi

Surendran, Antibacterial

Evaluation and phytochemical analysis of

Medicago sativa L. against some

Microbial

pathogens. Indian Journal of Science and Technology, 2011, Vol. 4 No.

5, ISSN: 0974- 6846.

Deshpande LM, Fritsche TR, Moet GJ, Biedenbach

DJ, Jones RN. Antimicrobial resistance

and Molecular epidemiology of vancomycin. resistant enterococci from North America And Europe: a report from the SENTRY antimicrobial surveillance program.

Diagn. Microbiol. Infect Dis. 2007.58:
Emmert EAB, Milner JL, Lee JC,

Pulvermacher KL, Olivares HA, Clardy J,

Handelsman J. Effect of canavanine

Activity of certain wild medicinal plants against

bovine mastitis isolated

Contagious pathogens. , 2012, Vol5,

ISSN- 0974-2441

.Effects of Salt Stress on Amino Fougere

$\mathrm{F}$,

Daniel, Le Rudulier, and John G. Streeter

Doss, H.Muhamed Mubaracki, M.Vijayasanthi and

R.Venkataswamy, IN-Vitro Antibacterial

Acid, Organic Acid, and Carbohydrate

Composition of Roots, Bacteroids, and

Cytosol of Alfalfa (Medicago sativa

L.)' Plant Physiol, 1991, .96; 1228-1236

Gao A, Hakimi SM, Mittanck CA, Wu Y, Woerner

MB, Stark DM, Shah DM, Liang J,

Rommens CMT. Fungal pathogen protection in potato by expression of a plant

defensin peptide. Nat.

Biotechnol.2000, 18, 1307-1310.

Gibbson S. Anti-staphylococcal plant natural products. Nat.

Prod. Rep. 21: 263-277.

Avato P, Bucci R, Tava A, Vitali C,

Rosato A, Bialy B, Jurzysta M (2006).

Antimicrobial activity of saponins from Medicago sp.:

Structure-activity

Relationship,

Phytother.2004, Res.

20: 454-457.

Ghani A Medicinal plants of Bangla Desh,The

Asiatic Society of Bangla Desh ,Dhaka, Bangla

Desh,2003,500-504

GomathI,R, Priyadharshini, Kirithika, K. Usha

Phytochemical Screening and free

Radical Scavenging Activity of

$163-170$.

(C) 2021, Scientific Research Journal

http://dx.doi.org/10.31364/SCIRJ/v9.i03.2021.P0321848

This publication is licensed under Creative Commons Attribution CC BY. 
Medicago Sativa Leavesijprbd,

$$
\text { 2013, Volume2 (4); 29_38, ISSN, }
$$

$2277-8713$

Grela E.R. Wartość pokarmowa lucerny i efektywność koncentratu PX w żywieniu zwierząt [Nutritive value of alfalfa and its utilization as proteinxanthophylss

Concentrate in animal

feeding]. In:

Alfalfa in human and animal's nutrition. T. 3.

$$
\text { Monographic E.R.Grela. }
$$

Stow.Rozw. Reg. Lokaln, 2008, "Progress"

Dzierdziówka - Lublin; 77-91

Grela E.R., Kowalczuk-E, Skład chemiczny, wartość

pokarmowa $\quad$ i $\quad$ przydatność

produktów z lucerny w żywieniu ludzi i zwierząt [Chemical composition,nutritive value and usefulness of alfalfa products in human and Animal nut]. In:

Alfalfa in human and animal's nutrition. T. 6. Monographic E.R. Grela.Stow.Rozw.Reg. Lokaln.

2010, Progress” Dzierdziówka- Lublin; 3.

Gray, A. M. and Flatt, P. R. Pancreatic and extrapancreatic effects of the traditional anti-

diabetic plant, Medicago sativa

(lucerne). Br J Nutr 1997;78(2):325-334. 9301421

G.Sheela Joy1, and Dr.Philomena George2. (2014) Antimicrobial screening of Alfalfa

Medicago Sativa in various bacterial strains, IJPDA; (2014, Vol: 2 Issue: 65- 69

Hong, Y.H., Chao, W., Chen, M., B. Lin. Ethyl acetate extracts of alfalfa (Medicago sativa L.) Sprouts inhibit lipopolysaccharideinduced inflammation in vitro and in vivo.

Journal of Biomedical

Science, 2009,

NSC $16 ; 1-12$

Jiang X P, Doyle M P. Growth Supplements for

Helicobacter pylori. J Clin Microbiol. : PMCID;

2000

PMC86644; 38(5): 1984- 1987.

Jiang X P, Doyle M P. Effect of environmental and substrate factors on survival and growth of Helicobacter pylori. J Food Prot.

1998; 61:929-933.

Kamel A and Khalid Al-Mutlaq, Selective herbicidal activity of an indole alkaloid isolated from

Rhazya

stricta Decne. Growing in

Saudi Arabia,Fourteenth Australian Weeds

Conference.2002, 270_273

MaharasMortensen, A., Kulling, S.E., Schwartz, H., Rowland, I., Ruefer, C.E., Rimbach, G.,

Cassidy, A., Magee, P., Millar, J., Hall,

W.L., Kramer Birkved, F., Sorensen, I.K.,

Sontag, G.2009 Analytical and

compositional aspects of isoflavones in food and theirbiological effects. Mol. Nutr. Food Res. 53; S266-S309.

Mirzaei,A., Mojtaba,A., Somayyeh,S., Mahsa,M, The Effects of Allium porrum and Medicago

Sativa on Iron Concentration in

Thalassemia Serums Life Science Journal

$$
\text { , (2013); 10(11s); 27_31 }
$$

Molgaard J, von Schenck H, Olsson AG. Alfalfa seeds lower low density lipoprotein cholesterol and apolipoprotein B concentrations in patients with type II hyperlipoproteinemia.

Www.scirj.org

(C) 2021, Scientific Research Journal http://dx.doi.org/10.31364/SCIRJ/v9.i03.2021.P0321848

This publication is licensed under Creative Commons Attribution CC BY. 
Atherosclerosis.(1987);65:173-179.

Nagarani.s,B., debnath, santhosh kumar,G., Ganesh kumar.A review herbs used as anticancer agent.International Research Journal of pharmacy (.2011), ISSN2230-8407;20_24

Nunes, C.,de Sousa Araújo, S., da Silva, J.M., Fevereiro, M.P.S., da Silva, A.B. Physiological responses of the legume model Medicago truncatula cv. Jemalongto water deficit.

Environ. Exp.,(2008) Bot. 63; 289-296.

Patel,R., Tirgar,P, Evaluation of Beneficial Effects of Medicago Sativa (Alfalfa) In Iron-

Overload Conditions. JCBPAT CODEN

(USA): J. Chem. Bio. Phy. Sci.Sec. B .2013 Vol.3, No.4; 2628-2643. Parekh Jigna and Sumitra V. Chanda In-vitro antimicrobial activity and phytochemical analysis of some Indian Medicinal Plants. Turk J, 2007, Biol. 31, 53-58.

Plaza, L,. de Ancos, B., Cano. P. M. Nutritional and healthrelated compounds insprouts and seeds of soybean (Glycine max), wheat (Triticum aestivum.L) and alfalfa (Medicago sativa) treated by a new drying method.

European Food Research and Technology. 2003, 216; 138-144.

Rafid Abdul wahid.A,W. inhibition the Growth of Some Malignant Cells Lines by Alfalfa Aqueous Extract,Iraqi Journal of Cancer and Medical, 2008, ; 46_50

Rana, M. G., Katbamna, R.V., Padhya., A. A., Dudhrejiya, A. D., Jivani, N. P., Sheth. NR. In

Takyi, E.E.K., Kido, Y.,Rikimaru, T., Kennedy, D.O. (1992). Possible use of alfalfa (Medicago vitro antioxidant and free radical

scavenging studies of alcoholic extractof Medicago

sativa 1. ROM. J. BIOL. - PLANT BIOL,2010,

VOLUME 55, No 1, ; 15-22.

Rehab Mohamed Atta El-Desoukey, Phytochemical and Antimicrobial Activity of Medicago sativa

(Alfalfa) as Source of Animal Food

Against Some Animal Pathogens,

Global Veterinaria.2015,14 (1):

136-141, ISSN 1992-6197.

Rosenthal, G. A., Nkomo. P. The natural abundance of L-canavanine, an active anticancer agent,

alfalfa, medicago sativa (L.). Pharm

Biol. 2000; 38; 1-6.

Rostagno, M.A., Villares, A., Guillamón, E., García-

Lafuente, A., Martínez, J.A., Sample preparation for the analysis of isoflavones from soybeans and soy foods.J.

Chromatogr. A, 2009, 1216; 2-29.

Sakarkar D.M., Deshmukh V.N.

Ethnopharmacological Review of Traditional Medicinal Plants for Anticancer Activity, International

Journal of PharmTech Research CODEN

(USA): IJPRIF ISSN : 0974-4304,2011,

Vol. 3, No.1,; 298-308

Silva L.R.Pereira M. J. Azevedo J., Gonçalves R. F.

Valentao P., de Pinho P. G., Andrade

PB. Glycine max (L.) Merr.,Vigna radiate L. and Medicago sativa L.

sprouts:Anatural source of bioactive

compounds. Food Research International,;

2013, 50; 167-175.

www.scirj.org

(C) 2021, Scientific Research Journal http://dx.doi.org/10.31364/SCIRJ/v9.i03.2021.P0321848

This publication is licensed under Creative Commons Attribution CC BY. 
nutrition: comparison of weight gained by rats fed on

alfalfa and a popular weaning diet. J. Sci.

Food Agric. 59,; $1992 ; 109-115$.

Safary A, Motamedi H, Maleki S and Seyyendnejad

SM A preliminary study on the antibacterial

activity of Quercus brantii against bacterial pathogens, particularly

enteric pathogens. Intl. J. Botany.2009,5(2),;176-180

Story JA. Alfalfa saponins and cholesterol interactions. Am J Clin Nutr

$1984 ; 39: 917-29$.

Wahid.A,W. nhibition the Growth of Some

Malignant Cells Lines by Alfalfa Aqueous

Extract,Iraqi Journal of Cancer and

Medical, 2008,46_50

Zanin V . A new nutritional idea for man: Lucerne leaf concentrate]. In:

Positive health impact
of alfalfa's leaves extract in human
nutrition."
Nowa idea żywienia dla
człowieka:
wyciąg z liści lucerny Dzierdziówka, 2009; 15-46

Www.scirj.org

(C) 2021, Scientific Research Journal

http://dx.doi.org/10.31364/SCIRJ/v9.i03.2021.P0321848

This publication is licensed under Creative Commons Attribution CC BY. 